\title{
PENERAPAN MODEL Z-SCORE UNTUK PREDIKSI KEBANGKRUTAN BANK BRI SYARIAH TAHUN 2014-2016
}

\author{
Muhlis \\ Dosen Manajemen Keuangan Syariah IAIN Parepare \\ Email: muhlismasin@gmail.com
}

\begin{abstract}
The application of the z-score model is done to find out the early condition possible to avoid the failure of bank management when experiencing financial difficulties that will trigger potential bankruptcy if the score category is below 2.99. The method used is the Altman Z-Score model by analyzing the financial statements of PT Bank BRI Syariah from 2014-2016. Based on the results of the research conducted, the z-score in 2014 was 5.13 and 6.24 in 2015, while in 2016 it was 5.24. Altman's score results indicate that the company is free from potential bankruptcy. The debt ratio has a guarantee of very good assets. Equity is ideal in fulfilling obligations

Abstrak: Penerapan model z-score ini dilakukan untuk mengetahui kondisi sedini mungkin menghindari kegagalan manajemen bank bila mengalami kesulitan keuangan yang akan memicu potensi kebangkrutan bila kategori skornya dibawah 2,99. Metode yang digunakan adalah model Altman Z-Score dengan menganalisis laporan keuangan PT Bank BRI Syariah dari tahun 2014-2016. Berdasarkan hasil penelitian yang dilakukan, nilai z-score tahun 2014 yaitu 5,13 dan 6,24 pada tahun 2015, sedangkan pada tahun 2016 yaitu 5,24. Hasil score Altman ini menunjukkan bahwa perusahaan bebas dari potensi kebangkrutan. Rasio utang mempunyai jaminan aktiva sangat bagus. Ekuitasnya sangat ideal dalam memenuhi kewajiban
\end{abstract}

Kata Kunci: Kebangkrutan, Laporan Keuangan, model analisis Altman Z-Score

I. PENDAHULUAN

\section{A. Latar Belakang Masalah}

Sejarah keberadaan perbankan

syariah di Indonesia bila dibandingkan

dengan bank konvensional, memang

lebih dahulu beroperasi bank

konvensional, hal ini sedikit tidaknya akan memberikan perbedaan dari segi

nasabah dan aktiva, melihat faktanya di sektor financial masih dominan bank konvensional. Namun dari berbagai pengkajian dan penelitian data-data menunjukkan perkembangan bank syariah luar biasa signifikan 
Muhlis, Penerapan Model Z-Score Untuk Prediksi Kebangkrutan Bank Bri Syariah ｜ 82

berkembangnya. Perusahaan yang agar bisa tetap bertahan dalam keadaan kesulitan keuangan akan mengurangi kondusif dan stabil. Kondisi akhir dari produknya yang bisa saja sebuah perusahaan termasuk mengakibatkan banyak perampingan, perbankan, baik perbankan bahkan berujung pada pemecatan konvensional maupun perbankan besar-besaran sehingga berpotensi syariah adalah kebangkrutan, dengan melahirkan pengangguran. Dengan dicirikan hilangnya kesempatan untuk demikian, penting sekiranya untuk mendapatkan profit. Kesulitan diwaspadai potensi kemungkinan keuangan merupakan penanda utama kebangkrutan. Manajemen bank harus adanya tanda-tanda kebangkrutan, bila jeli melakukan proteksi terhadap dibiarkan berlarut-larut dan tidak perusahaan dengan sedini mungkin ditangani dengan manajemen yang kemungkinan kebangkrutan. baik, maka perusahaan bisa saja

Kerugian besarpun jelas akan melanda perusahaan yang mengalami kesulitan keuangan yang menuju kepada kondisi kebangkrutan, terutama lembaga keuangan, khusunya perbankan syariah, karena nilai dari saham tersebut akan menagalami penurunan drastis, masyarakat tidak memiliki ketidakpercayaan kepada lembaga bank syariah tersebut.

Kinerja perusahaan seyogyanya menuju kebangkrutan.

Permasalahan yang sangat krusial adalah ditutupnya usaha karena bangkrut sehingga sulit untuk memperoleh income, karena pernyataan kebangkrutan adalah masalah hukum yang timbul karena kreditur atau pihak tertentu mengajukan gugatan kebangkrutan. ${ }^{1} \quad$ Kebangkrutan dijelaskan sebagai ketidaksanggupan untuk melunasi kewajibannya pada saat 
jatuh tempo. Pihak yang juga memiliki wewenang menyatakan kebangkrutan adalah pengadilan, yang nantinya akan melelang harta debitur yang dalam status barang sita yang nantinya akan diberikan kepada kreditur yang sesuai dengan haknya. Sehingga perusahaan sangat penting untuk memahami kemungkinan potensi terjadinya kebangkrutan.

Kebangkrutan sebuah perusahan dapat diprediksi melalui laporan keuangan, dengan menggunakan model analisis laporan keuangan. Manajemen perusahaan dapat mengatahui hasil-hasil yang dicapai melalui informasi dari laporan keuangannya serta dapat melakukan pengambilan keputusan yang disesuaikan dengan strategi perusahaannya.

Penelitian dari Universitas Tun Abdul Razak Kuala Lumpur United Kingdom of Great Britain and Northern
Ireland menemukan dukungan bahwa bank-bank Islam selama periode kondisi keuangan yang tertekan kurang berkeinginan untuk meningkatkan mengenai peraturan modal mereka untuk berbagi risiko. Secara intuitif, mereka lebih terdorong untuk terlibat dalam perilaku pengalihan risiko. Selain itu, perilaku pengalihan risiko ternyata memiliki potensi bank syariah asing yang jauh lebih tinggi daripada bank syariah domestik. Penelitian ini mengimplikasikan bagi bank syariah untuk membangun penyangga dana modal untuk menghadapi tekanan ke bawah selama ketidakpastian keuangan yang meningkat sekaligus memberikan perlindungan kepada nasabah. Agar bank syariah dapat terus memainkan peran mereka dalam mempromosikan pertumbuhan inklusif, mengurangi ketimpangan dan mempercepat pengentasan kemiskinan. ${ }^{2}$ Sama halnya dengan perbankan konvensional pada 
Muhlis, Penerapan Model Z-Score Untuk Prediksi Kebangkrutan Bank Bri Syariah ｜ 84

umumnya, untuk itu diperlukan pula suatu tools dan pengelolaan yang digunakan untuk mengukur serta memantau gejala-gejala yang memungkinkan perbankan syariah khususnya BRI Syariah dalam menghadapi risiko yang besar. Model alat tersebut seperti penggunaan $z-$ score.

Besarnya risiko yang dihadapi perbankan berkaitan dengan pengelolaan dana, mengharuskan mereka untuk berhati-hati, baik kemungkinan potensi yang bisa diperkirakan ataupun yang tidak dapat diperkiran bagi manajemen perbankan syariah. Terutama yang harus dikendalikan adalah risiko kerugian yang akan memicu terjadinya kebangkrutan.

Sebuah penelitian yang menggunakan $z$-score dari UEA menemukan bahwa Bank Islam UEA harus berupaya memperbaiki rasio yang akan mengakibatkan nilai mereka berdampak negatif, untuk lebih memahami kinerja masa lalu mereka dan menyadari posisi mereka saat ini di dalam industri ini. Metode Skor z-score dapat diadopsi oleh bank syariah UEA sebagai pendekatan evaluasi yang efektif untuk mendanai proyek kemitraan jangka panjang yang potensial termasuk usaha kecil dan menengah (UKM). Model z-score dapat diadaptasi oleh bank syariah sebagai pendekatan analisis risiko kredit independen untuk mengukur kompetensi dan kekuatan finansial dari proyek potensial. Bank-bank syariah di UAE pada umumnya sehat dan sehat secara finansial dan bahwa $z$-score adalah alat analisis yang menguntungkan yang dapat diadaptasi oleh bank-bank Islam di UAE untuk melengkapi teknik analisis keuangan lainnya untuk menetapkan rata-rata industri perbankan syariah. Studi ini juga menemukan bahwa rasio yang digunakan dalam menghitung $z$-score dapat dianggap memberikan indikator instrumental yang berharga. ${ }^{3}$ 
Pada dasarnya perbankan, termasuk PT. Bank Rakyat Indonesia Syariah juga sangat memerlukan model perencanaan yang diterapkan sesuai dengan keadaan situasi dan kondisi pada yang lalu, sekarang, serta prediksi pada masa mendatang. Tujuan dari rangkaian sistem peringatan yang lebih awal untuk meprediksi adanya kemungkinanan kesulitan keuangan yang akan merujuk kepada kebangkrutan, beberapa model yang bisa terapkan, salah satunya adalah alat model Altman z-score. Oleh karena itu, dibutuhkan kajian yang lebih mendalam dengan suatu informasi yang bisa diperoleh melalui laporan keuangan PT. Bank BRI Syariah yang disinergikan dengan model prediksi Altman z-score.

\section{B. Metode Penelitian}

Metode yang digunakan untuk mendapatkan hasil yang akurat penyelesaian menggunakan data adalah penelitian kuantitatif dengan data sekunder. Mengenai penulisan prediksi kebangkrutan untuk memperoleh hasil dilakukan dengan teknik yang sistematis agar memperoleh hasil yang akurat juga. Data-data laporan keuangan yang telah diperoleh lalu dianalisis dengan metode Altman $z$ score. Metode deskriktif yang digunakan merupakan metode pengumpulan data untuk memperoleh informasi mengenai keadaan indikasi tertentu, yang sesuai dengan fakta-fakta apa adanya. ${ }^{4}$

Altman menemukan lima jenis rasio keuangan yang dapat dikombinasikan untuk melihat perbedaan antara perusahaan yang bangkrut dan yang tidak bangkrut. ${ }^{5}$ Formula z-score Altman yaitu:

$\mathrm{Z}=0,012 \mathrm{X} 1+0,014 \mathrm{X} 2+0,033 \mathrm{X} 3+$ $0,006 \times 4+0,999 \times 5$

$\mathrm{X} 1=$ working capital to total assets

$\mathrm{X} 2$ = retained earning to total assets

$\mathrm{X} 3$ = earning before interest and taxes to total assets

$\mathrm{X} 4$ = market value of equity to book value of total debt

$\mathrm{X} 5=$ sales to total assets

$\mathrm{Z}=$ overall index 
Muhlis, Penerapan Model Z-Score Untuk Prediksi Kebangkrutan Bank Bri Syariah ～ 86

Untuk perusahaan non manufacturing

Model Z-Score, seperti perbankan yaitu:

$Z=6,56 \times 1+3,26 \times 2+6,72 X 3+$ $1,05 \mathrm{X} 4$

$\mathrm{Z}$ : nilai Z-Score

X1 : (Aktiva Lancar - Utang Lancar) /

Total Aktiva

X2 : laba ditahan / total asset

X3 : laba sebelum bunga dan pajak /

total asset

$\mathrm{X} 4$ : nilai buku ekuitas /total kewajiban

Tabel 1.

Pemberian Kategori Z-Score

\begin{tabular}{|c|c|c|}
\hline No & Z-Score & Indikasi \\
\hline 1 & $<1.81$ & Bankrut \\
\hline 2 & $1.81-2.99$ & $\begin{array}{c}\text { Grey area / } \\
\text { Zona of ignore }\end{array}$ \\
\hline 3 & $>2.99$ & $\begin{array}{c}\text { Tidak } \\
\text { Bangkrut }\end{array}$ \\
\hline
\end{tabular}

(Sumber: Mohammad, 2000)

Pemberian kategori perusahan yang bangkrut, grey area, sehat dapat ditunjukkan dengan kodifikasi, ${ }^{6}$ sebagai berikut:

1. Nilai $Z<1,81$ hasil kategori ini menunjukkan bahwa perusahaan tersebut dalam keadaan bangkrut.

2. Nilai $1,81<Z<2,99$ hasil kategori ini menunjukkan bahwa perusahaan tersebut dalam keadaan belum dinyatakan bangkrut tetapi juga didak dikategorikan sehat, tetapi perusahaan tersebut peluangnya masih bisa diselamatkan.

Nilai Z > 2,99 dikategorikan perusahaan yang sehat atau tidak bangkrut

\section{PEMBAHASAN}

\section{A. Hasil Analisis Laporan Keuangan PT Bank BRI Syariah 2014-2016}

Tulisan ini menggunakan data laporan keuangan PT Bank BRI Syariah yang telah dipublisikan. Kemudian, laporan keuangan dianalisa dengan menggunakan model prediksi kebangkrutan yang disebut dengan Metode z-score dengan menggunakan model perusahaan non manufacturing yang paling tepat untuk analisa prediksi 
kebangkrutan perbakan. Melalui penerapan model $z$-score maka bisa dijelakan hasilnya.

\section{Grafik 1.}

Aktiva Lancar PT Bank BRI Syariah 2014-2016

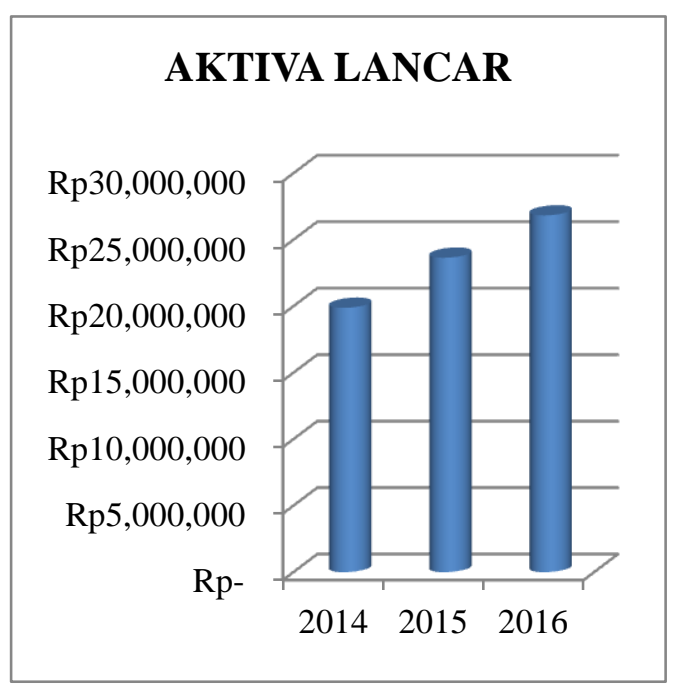

Sumber: Data Diolah

Data laporan keuangan PT Bank BRI Syariah tersebut menunjukkan bahwa aktiva lancar terus mengalami peningkatan tiap tahunnya dari tahun 2014 sebesar Rp19.883.632,- kemudian tahun 2015 berada pada angka Rp23.650.761,- ini mengindikasikan bahwa kondisi keuangan khususnya aktiva lancar PT
BRI Syariah dalam keadaan baik, dengan membuktikan aktiva lancer yang dimiliki mengalami kenaikan Rp26.834.707 selisih yang cukup signifikan positif dari tahun $2015 \mathrm{ke}$ 2016 yaitu Rp3.183.946,--

\section{Grafik 2.}

\section{Aktiva Tetap PT Bank BRI Syariah \\ 2014-2016}

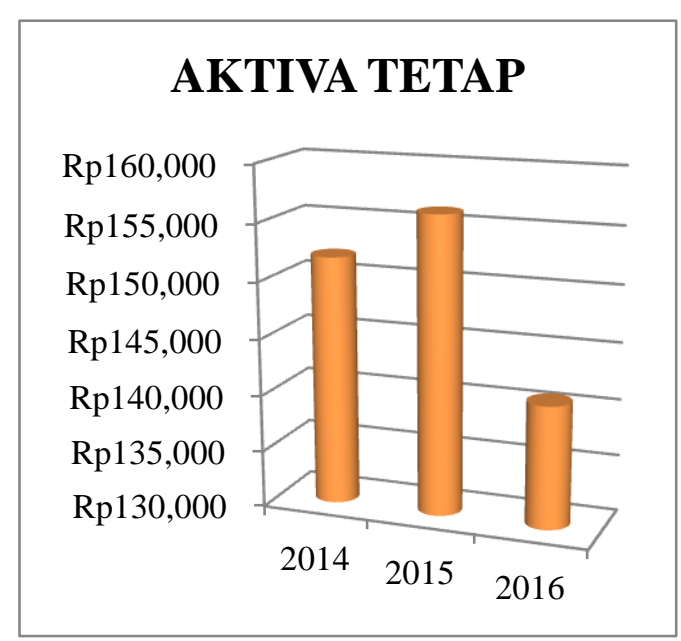

Sumber: Data Diolah

Grafik data laporan keuangan tersebut mengisyaratkan bahwa PT Bank BRI Syariah mengurangi berinvestasi pada aktiva tetap terbukti dari data 3 tahun terakhir tersebut menunjukkan data ditahun 2016 jumlah 
Muhlis, Penerapan Model Z-Score Untuk Prediksi Kebangkrutan Bank Bri Syariah ｜ 88

kekayaan aktiva tetapnya sebesar Rp140.816,- mengalami penurunan cukup drastis dari tahun sebelumnya yaitu Rp156.188,- melihat bahwa PT Bank BRI Syariah melakukan manuver untuk melakukan investasi disektor aktiva lancarnya di tahun 2016.

\section{Grafik 3.}

\section{Utang Lancar PT Bank BRI Syariah}

2014-2016

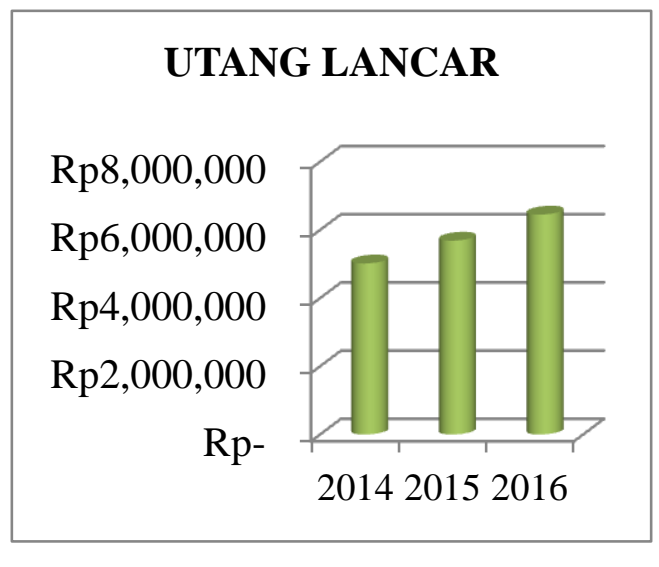

Sumber: Data Diolah

Perbandingan laporan keuangan

antara hutang lancar dengan aktiva lancar menurut rasio keuangan yang idealnya yaitu 1:2, melihat laporan keuangan hutang lancarnya cukup terkendalikan dengan sangat normal karena hutang lancar ditahun 2016 sebesar Rp6.450.555,- dengan jaminan aktiva lancar sebesar Rp26.834.707,hal ini tentunya adalah suatu fakta yang menunjukkan bahwa kemampuan PT Bank BRI Syariah untuk tetap eksis di bidang lembaga keuangan sangat percaya diri. Begitupun ditahun-tahun sebelumnya tetap utang lancar tetap dalam keadaan jaminan yang aman dari aktiva lancarnya.

\section{Grafik 4.}

Nilai Ekuitas PT Bank BRI Syariah 2014-2016

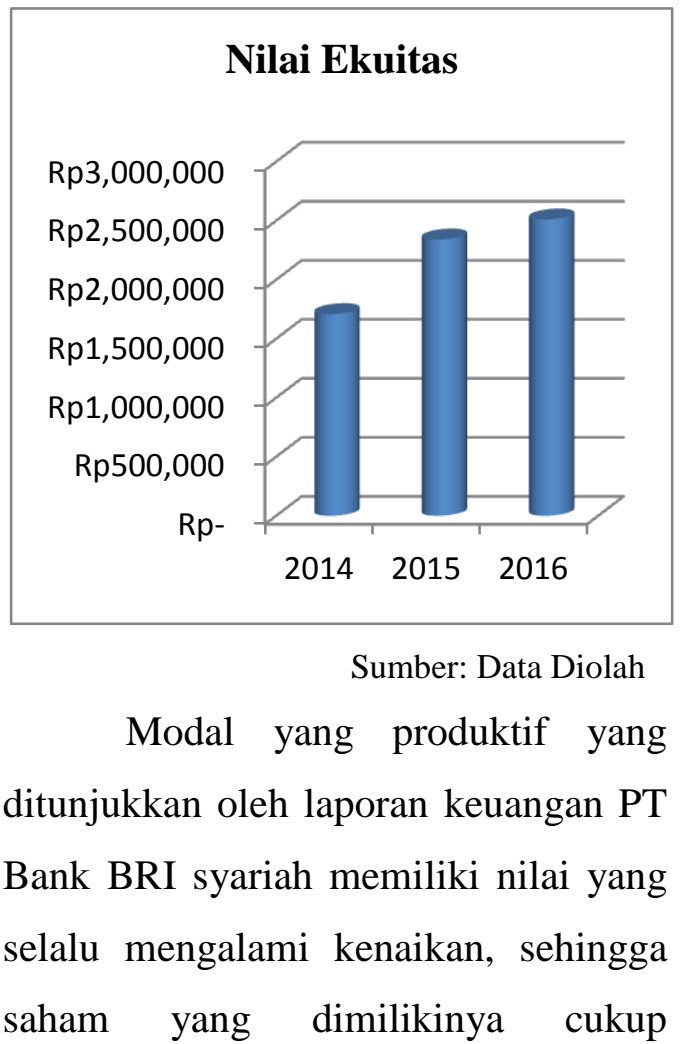


potensial untuknya cukup potensial untuk berkembang. Terlihat dari kemampuannya tahap demi tahap ekuitasnya mengalami kenaikan mulai dari tahun 2014 sejumlah Ekuitas pada sebuah bank harus mampu menganalisis dua sisi yaitu risiko dan potensi yang mampu menguntungkan perusahaan. Pada dasarnya saham PT Bank Syariah yang ditawarkan ke investor tentunya kinerja keuangan sangat mempengaruhi nilai pada kondisi dan kinerja keuangannya yang membutuhkan analisis yang secara komprehensif.

\section{B. Hasil Penerapan Model Z-Score PT Bri Syariah 2014-2016}

Rasio analisis laporan keuangan dengan menggunakan metode model Z-Score dengan hasil tabel sebagai berikut:

\section{Tabel 2.}

\section{Hasil Analisis Rasio PT Bank BRI} Syariah 2014-2016

\begin{tabular}{|c|c|c|}
\hline Keterangan & $\mathbf{2 0 1 4}$ & $\mathbf{2 0 1 5}$ \\
\hline $\mathrm{X}_{1}$ & 0,73 & 0,88 \\
\hline $\mathrm{X}_{2}$ & 0,02 & 0,01 \\
\hline $\mathrm{X}_{3}$ & 0,01 & 0,01 \\
\hline $\mathrm{X}_{4}$ & 0,30 & 0,36 \\
\hline \multicolumn{3}{|c|}{ Sumber: Data Diolah } \\
& $\begin{array}{c}\text { 1. } \\
\text { Perhitungan X1 (Modal Kerja } \\
\text { terhadap Total Aktiva) }\end{array}$ \\
\hline
\end{tabular}

Analisis modal kerja ini diperuntukkan untuk menghitung seberapa besar kemampuan PT Bank BRI Syariah dari tahun 2014-2016 dalam melunasi utang lancar dengan jaminan aktiva lancar yang tersedia. Semakin tinggi hasil rasio ini maka semakin bagus pada tingkat likuiditasnya terutama bagi perbankan syariah. Pada tahun 2014 hasil analisis rasio modal kerja terhadap total aktiva (X1) yaitu 0,73 untuk 2015 adalah 0,88 sedangkan pada tahun 2016 hasilnya 0,73 . Perhitungan dari 3 tahun terakhir bahwasanya tahun 2015 paling tinggi, sedangkan pada tahun 2016 mengalami penurunan. Hal ini disebabkan karena utang lancar mengalami kenaikan yang cukup signifikan, meskipun demikian tetap diimbangi dengan kenaikan daripada aktiva lancar pada sisi aktiva. Hasil ini harus bisa tetap 2016 dipertahankan oleh lembaga tersebut 0,73 0,02 dengan mampu menekan disisi utang 0 , đạncar dengan tetap memperhatikan sisi 0,30tiva lancarnya, agar PT Bank BRI Syariah tetap berjalan kondusif mampu memenuhi likuiditasnya dan 
Muhlis, Penerapan Model Z-Score Untuk Prediksi Kebangkrutan Bank Bri Syariah ｜９0

meningkatkan labanya dari tahun ke tahun. Modal Kerja PT Bank BRI Syariah sudah mampu menunjukkan arti pentingnya memenuhi dan mengoperasikannya. Karena, perusahaan yang kekurangan modal kerja dapat membahayakan kelangsungan hidup perusahaan, akibat tidak memenuhi likuiditas dan target laba yang diinginkan. Terpenuhinya modal kerja adalah salah satu ukuran kinerja manajemen perusahaan. ${ }^{7}$

2. Perhitungan X2 (Laba Ditahan terhadap Total Aktiva)

Hasil rasio ini bisa menginformasikan tentang seberapa produktifnya sebuah perusahaan yang terlihat dari asetnya. Disisi lain pada bagian rasio ini pula menganalisis tentang kemampuan mengukur keuntungan perusahaan yang dikumulatifkan yang mampu dihasilkan oleh PT Bank BRI selama tiga tahun. Tahun 2014 rasio laba ditahan terhadap total aktiva (X2) yaitu 0,02 kemudian untuk tahun 2015 turun hanya sekitar 0,01 sementara pada tahun 2016 kembali rasionya menjadi 0,02 .

Melihat dari hasil rasio ini PT Bank BRI dari sisi ini masih relative kecil kedepannya perlu untuk ditingkatkan lagi, agar mampu menghasilkan produktivitas yang lebih tinggi terutama untuk efektivitas investasinya. Karena pada dasarnya laba ditahan adalah cadangan yang menjadi saldo laba, pos ini bertambah dan berkurang tergantung dari kinerja perusahaan dan kebijakan deviden. ${ }^{8}$

3. Perhitungan X3 (EBT terhadap Total Aktiva)

Analisis ini memberikan informasi tentang perusahaan dalam menghasilkan profit sebelum melakukan tagihan bunga dan pajak. Namun, dalam hal ini kita tidak menyinggung tentang bunga, karena dalam perbakan syariah berlandaskan pada Al Qur'an dan Hadist sehingga dengan demikian tidak di perkenangkan untuk menggunakan dan mendapatkan income dari bunga dalam 
pelaksanaan usaha operasional. Berbeda dengan bank konvensional, bank syariah tidak menggunnakan tingkat suku bunga, karena bunga akan menurunkan minat untuk berinvestasi, bila hal ini terjadi maka akan mengurangi kesemptan kerja dan pendapatan sehingga akan menghambat pertumbuhan ekonomi. ${ }^{9}$

\section{Rasio Earning Before Taxt} terhadap Total Aktiva X3 pada PT Bank BRI Syariah tahun 2014, 2015 sampai dengan 2016 yaitu tetap relative konsisten masih minim yaitu 0,1 . Hasil ini menunjukkan masih perlu peningkatan pendapatan sebelum pajaknya. Tentunya dengan inovasi yang diharapkan kedepan melalui jasa pelayanan, penguatan disektor persaingan pelayanan tekhnologi serta memaksimalkan produk pendanaan dan produk pembiayaan yang ada pada PT Bank BRI Syariah.

\section{Perhitungan X4 (Nilai Pasar}

Ekuitas terhadap Nilai Buku Utang)

Nilai pasar yang digunakan untuk utang dan saham (ekuitas) merupakan cara terbaik dalam menentukan nilai kedua intrumen tersebut. ${ }^{10}$ Meski tidak selalu mudah untuk mendapatkan data pasar tetapi PT BRI Syariah telah menyiapkan data publikasi tersebut dalam laporan keuangannya. Penggunaan modal sebuah bank baik dari modal sendiri ataupun modal pinjamaan seharusnya melakukan pengamatan yang secara cermat agar mendapatkan hasil sesuai dengan tujuan perusahaan.

Melalui rasio ini kita dapat memperoleh masukan tentang pengelolaan hasil dari modal tersebut. Nilai rasio dari nilai pasar ekuitas terhadap nilai buku utang (X4) PT Bank BRI Syariah menunjukan angka di level 0,30 pada tahun 2014, tahun 2015 berada pada angka sekitar 0,36, sedangkan pada tahun 2016 kembali mengalami penurunan pada angka 0,30 . Hasil data tersebut menunjukkan dari tiga tahun mengalami tren yang cukup bagus, selama tiga tahun rasio tertinggi ada pada tahun 2015 yaitu 0,36 rasio ini menunjukkan bahwa PT Bank BRI Syariah mengalami kemampuan yang rata-rata cukup bagus selama tiga tahun 
Muhlis, Penerapan Model Z-Score Untuk Prediksi Kebangkrutan Bank Bri Syariah ｜ 92

dalam memenuhi kewajibannya.

2014-2016

\begin{tabular}{|c|c|c|}
\hline Hasil ini sudah memenul Keterangan & 2014 & 2015 \\
\hline$X_{1} \cdot 6,56$ & 4,76 & 5,76 \\
\hline kecukupan modal & 0,04 & 0,05 \\
\hline perusahaan, terpenuhinya modal akan & 0,01 & 0,05 \\
\hline meningkatkan kepercayaan masyarakat & 0,32 & 0,38 \\
\hline 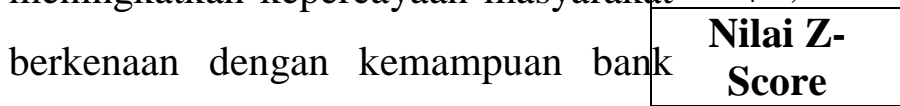 & 5,13 & 6,24 \\
\hline untuk memenuhi kewajibannya yang & $\begin{array}{c}\text { Tidak } \\
\text { Bangkrut }\end{array}$ & Tidak Bangkrut \\
\hline
\end{tabular}

keyakinan akan kelanjutan operasi bank. Disis lain terpenuhinya modal akan memenuhi regulasi permodalan yang sehat menurut otoritas moneter. ${ }^{11}$

\section{Klasifikasi Perusahaan(Altman Z-Score)}

Hasil analisis perhitungan melalui variabel-variabel keuangan tersebut, yang terdiri dari empat variabel tersebut kemudian dimasukkan ke dalam suatu formulasi selanjutnya yang di rancang melalui analisis diskriminan untuk manghasilkan zscore Altman. Hasil z-score akan menentukan nilai akhir yang akan dikategorikan terindikasi bangkrut atau tidak, kategori hasil rasio tersebut dapat ditunjukkan sebagai berikut ini.

Tabel 3.

\section{Hasil Z-Score PT Bank BRI Syariah}

Sumber: Data Diolah

Melalui hasil pengamatan penerapan model altman z-score pada PT Bank BRI Syariah dapat dijelaskan bahwasanya selama tiga tahun hasil analisis z-score menunjukkan PT Bank BRI Syariah tidak dalam keadaan terindikasi bangkrut. Penilaian ini menunjukkan rata-rata dari tiga tahun semuanya di atas ambang batas melebihi 2,9. Bahkan pada tahun 2015 data menunjukkan levelnya berada pada angka 6,24. Sebelumnya pada tahun 2014 berada pada angka 5,13. Meski ditahun 2016 mengalami Score penurunan dari tahun sebelumnya yaitu 5,24 hasil ini masih sangat jauh dari kategori terindikasi bangkrut.

Dengan demikian PT Bank BRI Syariah dalam keadaan kondusif dan aman dari keadaan disinyalir dalam. 
Walaupun demikian PT Bank BRI Syariah harus tetap waspada dengan keadaan-keadaan yang bisa membuat prestasi keuangan perusahaan menurun. Menjaga kestabilan perusahaan terutama berkaitan dengan kinerja keuangan yang sangat sensitif terutama bagi bank-bank syariah, yang equity lebih banyak dari modal Dana Pihak Ketiga (DPK). Karena kitidakmampuan menjaga kestabilan keuangan akan berdampak buruk pada prestasi perusahaan.

Dampak buruk yang bisa dilihat langsung dari permasalahan keuangan dan harus dihindari bagi perusahaan antara lain berdampak pada likuiditas bank. Kemacetan dalam memenuhi likuiditasnya jelas akan sangat mempengaruhi kinerja perusahaan terutama PT. Bank BRI Syariah dalam hal memenuhi kewajibankewajibannya. Bahwasanya kesulitan usaha merupakan kondisi kontinum mulai dari kesulitan keuangan yang ringan seperti masalah likuiditas, sampai pada permasalahan keuangan yang lebih serius, yaitu tidak solvabel dengan utang lebih besar dibandingkan dengan aset. Situasi ini perusahaan sudah dikatakan bangkrut. ${ }^{12}$

Tetapi hal ini mampu di jawab oleh PT Bank BRI Syariah dengan menunjukkan aktiva lancarnya yang cukup bagus terlihat dari rasio keuangannya pada Perhitungan Modal Kerja terhadap Total Aktiva (X1) yang menunjukkan nilai pada level angka 0,73 pada tahun 2014, tahun 2015 menagalami rasio kenaikan 0,88 dan pada tahun 2016 kembali menempati pada angka 0,73 hasil rasio ini diatas standar jaminan, seperti pada komponen utang lancar yang harus dijamin dua kali lipat oleh aktiva lancar sesuai dengan standar kesehatan bank syariah, agar mampu memenuhi likuiditasnya.

\section{Grafik 5.}

\section{Grafik Nilai Z-Score PT Bank BRI} Syariah 2014-2015

Nilai Z-Score PT Bank BRI Syariah

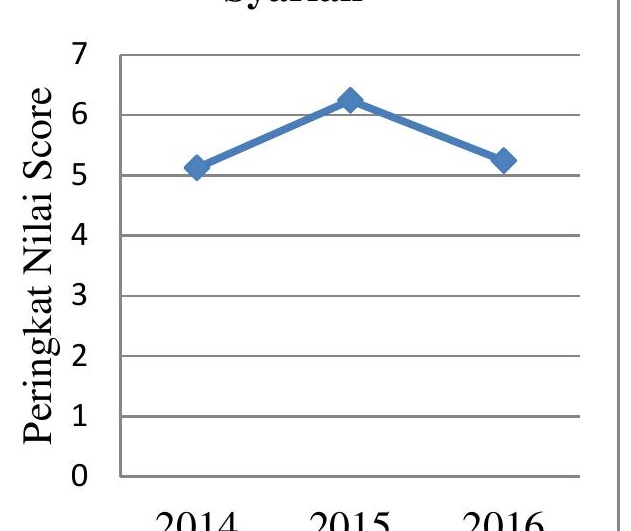


Muhlis, Penerapan Model Z-Score Untuk Prediksi Kebangkrutan Bank Bri Syariah ｜ 94

\section{Sumber: Data Diolah \\ Data grafik dari gambar} tersebut menujukkan alur pergerakan yang sangat stabil meskipun terjadi fluktuasi tren namun tetap di atas ambang batas normal aman dari posisi potensi kebangkrutan. Bahkan pada tahun 2015 nilai peringkat $z$-score rasio laporan keuangannya berada pada level angka 6,24 hal ini sangat bagus sekali, tahun sebelumnya juga yaitu tahun 2014 berada pada level 5,13 kemudian tahun 2016 posisi nilainya yaitu 5,24 mengingat angka ini menunjukkan PT Bank BRI Syariah berada pada zona aman.

\section{Pengelolaan manajemen}

keuangan PT Bank BRI Syariah sangat diperlukan agar perusahaan bisa terhindar dari risiko yang akan memperburuk keadaan perusahaan, terutama berkaitan dengan risiko yang mengarah kepada kebangkrutan. Risiko kebangkrutan yang dipicu dari kesulitan keuangan, tidak hanya akan memperparah keuangan, tetapi lebih dari itu akibatnya. Kondisi kesulitan keuangan akan merujuk pada ketidakmampuan perusahaan untuk memnuhi kewajiban-kewajibannya seperti pembayaran gaji dan upah karyawannya. Bila hal ini terus berlanjut maka otomatis pihak perusahaan bila sudah tidak mampu membayar kewajibannya hal ini bisa menimbulkan pemutusan kerja, dan akan melahirkan pengangguran. Pengangguran adalah hal yang menyulitkan perekonomian bagi negara-negara berkembang seperti Indonesia, selain kemiskinan itu sendiri.

Kebangkrutan terjadi bukan hanya karena masalah kesulitan keuangan sebagain permasalahan satusatunya, tetapi juga kesalahan pengelolaan manajemen perusahaan. Setiap proses kegiatan usaha yang dilakukan oleh sebuah perusahaan membutuhkan manjemen lebih terutama berkaitan untuk meraih 
tujuan-tujuan perusahaan terutama dalam dunia perbankan syariah dengan proses manejemen syariah yang handal dan bermutu.

Peranan dari sektor perbankan syariah sangat penting mengingat perbankan, sebagai salah satu pilar perekonomian dengan fungsi keberadaanya sebagai lembaga intermediasi dari masyarakat yang memiliki kelebihan dana kepada masyarakat yang kekurangan dana namun mengharapkan perantara lembaga keuangan seperti PT Bank BRI Syariah untuk memfasilitasi dana pinjaman agar mampu memulai, menjalankan dan mengoperasikan usahanya dengan akad perjanjian yang sesuai dengan syariah dalam landasan al-Qur'an dan sunah.

Hasil pengelolaan Altman zscore pada komponen laporan keuangan PT Bank BRI Syariah tahun 2014-2016 dengan hasil yang menunjukkan bebas dari tanda-tanda potensi kebangkrutan, analisis ini menunjukkan manajemen PT Bank BRI Syariah dilihat dari kinerja keuangannya mampu memenuhi kewajiban-kewajibannya sebagai lembaga keuangan syariah dan berhak untuk tetap eksis melakukan pelayanan produk dan jasa keaungan syariah.

Penulisan penerapan dari hasil model Altman z-score ini pada laporan keuangan PT Bank Syariah mulai tahun 2014-2016, diharapkan bisa memberikan kontribusi bagi manajemen perusahaan dan pihakpihak yang berkepentingan untuk memajukan persaingan dalam dunia perbankan syariah, khususnya PT Bank BRI Syariah. Agar perusahaan bisa tetap bersaing mendorong, meraih, dan mempertahankan prestasi kinerjanya sebagai pilar-pilar sektor perekonomian dalam memberikan layanan produk dan jasa bagi nasabah PT Bank BRI Syariah pada khususnya dan perbankan syariah pada umumnya di seluruh Indonesia.

\section{PENUTUP}

Berdasarkan penulisan penerapan metode Altman z-score pada PT Bank BRI Syariah Tahun 2014-2016 dapat ditarik kesimpulan 
Muhlis, Penerapan Model Z-Score Untuk Prediksi Kebangkrutan Bank Bri Syariah ～ 96

bahwa hasil model Altman z-score pada PT Bank BRI Syariah menghasilkan nilai di atas ambang batas 2,90 kriteria ini menunjukkan bahwa dari tiga tahun tidak mengalami potensi kebangkrutan. Data analisis $z-$ score dari tiga tahun hasil tertinggi ada pada tahun 2015, disusul tahun 2016 dan kemudian 2014 pada PT Bank BRI Syariah.

Hasil perhitungan modal kerja terhadap total aktiva (X1) dari tahun 2014-2016 ini menunjukkan angka yang cukup bagus, hasil ini harus bisa tetap dipertahankan dengan mampu tetap menjamin utang lancar dengan tetap memperhatikan sisi aktiva lancarnya, sehingga hal ini harus tetap dijaga bahkan semakin ditingkatkan dalam menyongsong era yang akan datang.

Komponen yang membutuhkan perencanaan yang cermat adalah pada bagian pendapatan, khususnya pendapatan sebelum pajak EBT (X3) terhadap aktiva dan juga rasio perhitungan laba ditahan (X2) oleh PT Bank BRI Syariah yang masih konsisten relatif kecil, otomatis akan mempengaruhi total ekuitas syariah, komponen ini harus ditingkatkan oleh agar semakin memperkuat modal yang dimilki PT Bank BRI Syariah. Sehingga Perbankan Syariah lebih khusus PT Bank Syariah harus memanfaatkan dan memaksimalkan peluang-peluang yang ada karena masyarakat juga sudah mulai memahami keberadaan Bank Syariah khususnya PT Bank BRI Syariah seiiring dengan keadaan yang termasuk kategori perbankan yang bebas dari kesulitan keuangan atau bebas dari indikasi bangkrut.

${ }^{1}$ Harianto, Farid dan Siswanto Sudomo, Perangkat Teknik Analisis Investasi di Pasar Modal Indonesia, (Jakarta: BEJ, 1998), h. 366.

${ }^{2}$ Mohd Yaziz Mohd Isa, Md. Zabid Hj Abdul Rashid, "Regulatory capital funds and risk-sharing behavior in distressed financial conditions: an empirical analysis on Islamic banks in Malaysia", Journal of Financial Reporting and Accounting, JFRA-06-20150066

${ }^{3}$ Obaid Saif H. Al Zaabi, "Potential for the application of emerging market Z- score in UAE Islamic banks", International Journal of Islamic and Middle Eastern Finance and 
Management, Vol. 4 Issue: 2, 2011. pp.158-17.

${ }^{4}$ Arikunto, Suharsimi. 2010. Prosedur Penelitian, Edisi Revisi (Yogyakarta: Rineka Cipta,2005) h. 234.

${ }^{5}$ Weston, J. Fred dan Thomas E. Copeland. 2010. Manajemen Keuangan, Alih Bahasa oleh A. Jaka Wasana dan Kibrandoko, Edisi Revisi, Jilid 1 dan 2.Jakarta: Binarupa Aksara. 2010, h. 288.

${ }^{6}$ Mohamad Muslich, Manajemen Keuangan Modern (Analisis, Perencanaan,dan Kebijaksanaan). (Jakarta: Bumi Aksara: 2000), h. 60 .

${ }^{7}$ Kasmir, Analisis Laporan Keuangan, (Jakarta: PT Rajagrafindo, 2013), h. 253.

8Toto Prihadi, Analisis Laporan Keuangan Lanjutan: Proyeksi dan Valuasi, (Jakarta: PPM Manajemen, 2012), h. 54.

${ }^{9}$ Heri Sudarsono, Bank dan Lembaga Keuangan Syariah: Deskripsi dan ilustrasi, Ed. 4, (Yogyakarta: Ekonisia Kampus Ekonomi UII, 2013), h. 23.

${ }^{10}$ Toto Prihadi, Analisis Laporan Keuangan, h. 266.

${ }^{11}$ Cand. Taswan, Manajemen Perbankan: Konsep Teknik \& Aplikasi. Edisi II. (Yogyakarta: UPP STIM YKPN, 2010), h. 214 .

${ }^{12}$ Mamduh M. Hanafi, Manajemen Keuangan, Edisi 1, (Yogyakarta: BPFE, 2013), h. 638 .

\section{DAFTAR PUSTAKA}

Arikunto, Suharsimi. Prosedur Penelitian, Edisi Revisi, Yogyakarta: Rineka Cipta. 2010 .

Al Zaabi, Obaid Saif H. Potential for the application of emerging market Z-score in UAE Islamic banks", International Journal of Islamic and Middle Eastern Finance and Management. 2011.

Fred, Weston, J., dan Thomas E.

Copeland. Manajemen
Keuangan, Alih Bahasa oleh A.
Jaka Wasana dan Kibrandoko,
Edisi Revisi, Jilid 1 dan
2.Jakarta: Binarupa Aksara.
2010.

Harianto, Farid dan Siswanto Sudomo, Perangkat Teknik Analisis Investasi di Pasar Modal Indonesia, Jakarta: BEJ. 1998.

Isa, Mohd Yaziz Mohd, Md. Zabid $\mathrm{Hj}$ Abdul Rashid, Regulatory capital funds and risk-sharing behavior in distressed financial conditions: an empirical analysis on Islamic banks in Malaysia, Journal of Financial Reporting and Accounting, JFRA. 2015.

Kasmir, Analisis Laporan Keuangan, Jakarta: PT Rajagrafindo. 2013.

Muslich, Mohamad, Manajemen Keuangan Modern : Analisis, Perencanaan, dan Kebijaksanaan Jakarta: Bumi Aksara. 2000.

Prihadi, Toto, Analisis Laporan Keuangan Lanjutan: Proyeksi dan Valuasi, Jakarta: PPM Manajemen. 2012.

Sudarsono, Heri, Bank dan Lembaga Keuangan Syariah: Deskripsi dan ilustrasi, Ed. 4. Yogyakarta: Ekonisia Kampus Ekonomi UII. 2013. 
Taswan, (Cand)., 2010, Manajemen Perbankan: Konsep Teknik \& Aplikasi. Edisi II. Yogyakarta: UPP STIM YKPN. 